\title{
вмJ Global Health Article processing charges are stalling the progress of African researchers: a call for urgent reforms
}

\author{
Juliet Nabyonga-Orem (D) ," James Avoka Asamani (D) ," Thomas Nyirenda (D) ,2 \\ Seye Abimbola (1) ${ }^{3}$
}

To cite: Nabyonga-Orem J, Asamani JA, Nyirenda T, et al. Article processing charges are stalling the progress of African researchers: a call for urgent reforms. BMJ Global Health 2020;5:e003650. doi:10.1136/ bmjgh-2020-003650

Received 6 August 2020 Revised 31 August 2020 Accepted 1 September 2020

Check for updates

C) Author(s) (or their employer(s)) 2020. Re-use permitted under CC BY-NC. No commercial re-use. See rights and permissions. Published by BMJ.

${ }^{1}$ UHC Life Course Cluster, World Health Organization Regional Office for Africa, Brazzaville, Congo

${ }^{2}$ The European \& Developing Countries Clinical Trials Partnership (EDCTP), Francie van Zijl Drive, Cape Town 7505 , South Africa

${ }^{3}$ School of Public Health, University of Sydney, Sydney, New South Wales, Australia

Correspondence to Dr Juliet Nabyonga-Orem; nabyongaj@who.int

\section{INTRODUCTION}

The recognition and progression of an academic or research career is hinged on the number and quality of publications in highimpact journals. Open access publication, especially in high-impact journals, confers a significant citation (ie, recognition and progression) advantage. ${ }^{1}$ However, there is increasing demand for publication fees or article processing charges (APCs), by highimpact open access journals. Where does this leave African researchers who earn too little (personal income or research grants) to publish in such top-tier open access journals? Already, Africa contributes much too little (1.3\% in one estimate) to research publication output globally, ${ }^{2}$ of which $52 \%$ are accounted for by just three middle-income countries-South Africa, Nigeria and Kenya.

The local and global challenges that limit the publication and citation potential of African researchers are well known. For example, at the local level, there are very few full-time researchers (5 per million people in low-income countries vs 363 per million people in high-income countries), ${ }^{3}$ with weak investment in research (and academic writing) capacity, ${ }^{4}$ research infrastructure and research governance. ${ }^{5}$ And at the global level, there are exploitative international research collaborations, gender constraints affecting female researchers ${ }^{6}$ and inability to attract global research funding. Now, APCs are systematically excluding African researchers from publishing in high-impact open access journals. Researchers in Africa are typically not in a position to win or have access to grants that cover APCs as eligible research expenditure.

A 2018 analysis showed that countries of the WHO African region received only $0.65 \%$ of global research grants. ${ }^{3}$ This is not peculiar to Africa-for example, in Pakistan, only
$2 \%$ of researchers had received more than two research grants 15 years after doctoral training. ${ }^{7}$ In 2008, WHO African region adopted the Algiers Declaration-to invest $2 \%$ of member countries' national health budget in health research. But an assessment in 2014 showed that only 2 out of 39 countries met that commitment. ${ }^{5}$ Local research grant initiatives have been hard to sustain. And so, researchers are left 'hanging in there' through self-sponsored studies, or riding on international collaborations often driven by the interest of funders-which may be exploitative, ${ }^{9}$ or have limited local relevance. ${ }^{10}$

In this editorial, based on our collective and diverse experiences as African researchers, editors and funders, we highlight the plight of fellow African researchers whose desire to contribute to global knowledge, progress their careers and gain recognition for their work is hampered by deterring APCs in the face of meagre resources. In addition, to address this pressing challenge, we offer and call for urgent reforms by governments, local and international funders and donors, and the scientific publishing industry.

\section{OPEN ACCESS AS A SOLUTION AND A PROBLEM}

The traditional model of high-impact journals has not been open access-individuals pay directly to access an article or gain access through institutional subscription. But these tend to be unaffordable for individuals and institutions in low- and middle-income countries. To address the persistent problem of limited access to scientific publications, the Hinari Access to Research for Health programme was set up by WHO together with major publishers. The Hinari programme enables researchers in low- and middleincome countries to gain free access to one of the world's largest collection of biomedical 
and health literature. However, this provision excludes countries with a gross national product per capita of US\$1500. ${ }^{11}$

In part, open access publishing emerged as a solution to this problem, with journals requiring that authors pay APCs to publish their papers. However, the value of open access publishing (ie, facilitating free access and inclusion in the dissemination and use of scientific research) exists in tension with its financing model (ie, publishers may need to 'raise publishing fees well beyond the level that scientists are willing [and able] to pay'). ${ }^{12}$ Journals considered to charge lower than industry rates, charge average APC between US $\$ 1350$ and US $\$ 2250$, premium journals charge up to $\$ 3900,{ }^{13} 14$ and some charge even more for research papers-for example, $£ 3000$ in BMJ Global Health and US\$5000 in Lancet Global Health. In some cases, partial or full waivers are granted to researchers from low- and middle-income countries, thus helping to improve the meagre research output from Africa.

However, researchers in Africa are often so poorly supported that they are unable to afford partial waivers or discounted APCs when granted. Very often, they are not eligible for waivers, because they are based in a country with high enough per capita income, even though such high per capita income may not reflect in the extent to which the country's government supports researchers. In other instances, researchers from low-and middle-income countries may be ineligible for waivers because they have a named high-income country coauthor on their manuscript, even when they have received little or no financial support through such a coauthor, thus constituting a potential disincentive for collaboration. In many other instances, the waiver process is not transparent.

\section{PUBLICATION FEES VERSUS SALARIES}

Fee waiver decisions are typically based on measures of per capita income of the country in which (all) the authors are based. Without access to research grants that cover publication charges, African researchers are often left with no option but to pay out of pocket to cover APCs. This is a cause for concern. Low salaries in African universities is a major reason why researchers leave academia for consultancy or migrate to high-income countries. ${ }^{15}{ }^{16}$ Even top earning academics in Africa (ie, in South Africa) earn an average of $53 \%$ (range: $45 \%-60 \%$ ) of what their counterparts earn in high-income countries like the USA-and are much worse off when compared with Australia, Hong Kong and Singapore. ${ }^{17}$

To illustrate the gravity of this issue, we use income data of top medical consultants or specialists (some of whom double as researchers) in nine African countries as a marker of earnings of health researchers (table 1). They earn US\$449-US\$5987 per month, depending on the income status of their country and the priority their country gives to their income. If a journal levies APC of about US $\$ 2600$ per article (as is common), researchers in some countries may have to give up nearly 6 months of
Table 1 Average income of medical specialists/consultants in selected countries (before tax)

\begin{tabular}{llccl}
\hline No & Country & $\begin{array}{l}\text { Average } \\
\text { annual } \\
\text { income } \\
\text { (US\$) }\end{array}$ & $\begin{array}{l}\text { Average } \\
\text { monthly } \\
\text { income } \\
\text { (US\$) }\end{array}$ & Source \\
\hline 1 & Ethiopia & 5391 & 449 & HLMA, 2020 \\
\hline 2 & Botswana & 68601 & 5717 & SADC, 2019 \\
\hline 3 & Eswatini & 31959 & 2663 & SADC, 2019 \\
\hline 4 & Ghana & 29821 & 2485 & Estimated \\
\hline 5 & Kenya & 49800 & 4150 & HRH strategy, \\
\hline 6 & Namibia & 71841 & 5987 & HLMA, 2019 \\
\hline 7 & Seychelles & 63303 & 5275 & NHWA, 2020 \\
\hline 8 & Sierra Leone & 28720 & 2393 & HLMA, 2019 \\
\hline 9 & Zambia & 26450 & 2204 & NHWA, 2019 \\
\hline & Mean & 41765 & 3480 & \\
\hline & Lowest & 5391 & 449 & \\
\hline & Highest & 71841 & 5987 & \\
\hline
\end{tabular}

HLMA, health labour market analysis; $\mathrm{HRH}$, human resource for health; NHWA, national health workforce account; SADC, Southern Africa Development Community.

their entire earnings (before tax) to finance one publication-and even when $50 \%$ waiver is granted as done in some cases, between 1 and 3 months' income has to be forgone per publication. In such instances, anything short of a full waiver is inappropriate.

The constraint posed by publication fees limits the volume of publications by African researchers, especially in high-impact open access journals. They may choose to publish in obscure journals that are not accessible in frequently searched electronic databases; they may fall prey to predatory journals who bait researchers with significantly lower publishing fees; or they may not publish at all, or publish only infrequently. ${ }^{18}$ While national income status is a predictor of publication outputs, ${ }^{2}$ it is only a partial determinant of the ability of individual researchers to pay APCs. There is the additional factor of the extent to which a country supports researchers (with their salary as a proxy). Both factors do not always align.

\section{A CALL FOR URGENT REFORMS}

Even though unmatched with commensurate investment, adopted resolutions and declarations dating back two decades ${ }^{19-24}$ testify to the broad agreement that research is important for health and development in Africa. Why invest so little and so inequitably? Constraints on the ability of African researchers to publish in highimpact journals are dire and go beyond APCs, but APCs are an increasingly serious, stalling constraint. Where do African researchers turn for a solution? To their governments, to the scientific publishing industry, or to local 
and international donors and funders? What reforms are necessary to support African researchers? We offer three sets of urgent and necessary reforms.

First, to provide fair and equitable opportunity for researchers in Africa (but also more broadly for researchers across many low- and middle-income countries), the stifling effect of APCs on publications must now be considered a crisis. Governments, funders and donors need to play their part by investing in health research, and supporting researchers with grants, and remunerating them as appropriate. Governments, funders, and donors should also strengthen research governance and foster mutually beneficial partnerships in collaborative research-for example, international research grants should come with funds to cover APCs, and provide capacity building and mentorship support for participating African researchers to publish their work in highimpact open access journals as lead authors.

Second, the fee, discount and waiver policies of open access scientific publishers need to incorporate considerations of capacity to pay. It is not fair to impose flat fees, or discount and waiver conditions. The profit margin in the scientific publishing industry is estimated at $20 \%-30 \%$, so there is much room to make concessions for African researchers. ${ }^{14}$ Policies that limit the participation of African researchers in the global academic discourse are inconsistent with the mission of academic (and especially global health) journals. In addition, the 'public' has a major stake in scholarly publishing. Much of the costs of peer review (a major contributor to the costs of scientific publishing) are covered by researchers, essentially at 'public' expense. Hence, the rationale for fees, discounts and waivers should be more transparent, and should take into consideration salaries earned by researchers and their ease of accessing grants.

Third, there is a need to diversify the range of highimpact open access journals available to African researchers, as an essential pillar of ongoing efforts to decolonise academia (and global health) ${ }^{25}$ There is now no reason why African journals should not be archived in frequently searched electronic databases. Like journals based in London, Boston or Geneva, African journals should aspire to be high-impact open access journals that have a global reach, with fees, discount and waiver policies set with African researchers at the centre of consideration. Building such African academic publishing infrastructure will require concerted efforts led by African researchers, in partnership with colleagues all over the world, and supported by the scientific publishing industry, by African governments and by local and international funders and donors.

Twitter Juliet Nabyonga-Orem @julienabyonga, James Avoka Asamani @jamesavoka and Seye Abimbola @seyeabimbola

Contributors JNO and JAA conceived the study. JNO and JAA led the drafting of the manuscript. TN and SA substantially contributed to the drafting of the manuscript. All authors reviewed and approved the final manuscript.

Funding The authors have not declared a specific grant for this research from any funding agency in the public, commercial or not-for-profit sectors.
Disclaimer The content of this article represents the view of the authors in their individual capacity and not the institutions they work for.

Competing interests SA is the Editor in Chief of BMJ Global Health.

Patient consent for publication Not required.

Provenance and peer review Not commissioned; internally peer reviewed.

Data availability statement There are no data in this work.

Open access This is an open access article distributed in accordance with the Creative Commons Attribution Non Commercial (CC BY-NC 4.0) license, which permits others to distribute, remix, adapt, build upon this work non-commercially, and license their derivative works on different terms, provided the original work is properly cited, appropriate credit is given, any changes made indicated, and the use is non-commercial. See: http://creativecommons.org/licenses/by-nc/4.0/.

\section{ORCID iDs}

Juliet Nabyonga-Orem http://orcid.org/0000-0002-1061-8678 James Avoka Asamani http://orcid.org/0000-0003-0620-6010

Thomas Nyirenda http://orcid.org/0000-0003-4727-7130

Seye Abimbola http://orcid.org/0000-0003-1294-3850

\section{REFERENCES}

1 Breugelmans JG, Roberge G, Tippett C, et al. Scientific impact increases when researchers publish in open access and international collaboration: a bibliometric analysis on poverty-related disease papers. PLoS One 2018;13:e0203156.

2 Uthman OA, Wiysonge CS, Ota MO, et al. Increasing the value of health research in the WHO African Region beyond 2015--reflecting on the past, celebrating the present and building the future: a bibliometric analysis. BMJ Open 2015;5:e006340.

3 World Health Organisation. Global Observatory on Health R\&D. Geneva, 2018. https://www.who.int/research-observatory/ benchmarking/researchers income/en/

4 Kumwenda S, Niang EHA, Orondo PW, et al. Challenges facing young African scientists in their research careers: a qualitative exploratory study. Malawi Med J 2017;29:1-4.

5 Rusakaniko S, Makanga M, Ota MO, et al. Strengthening national health research systems in the WHO African Region - progress towards universal health coverage. Global Health 2019;15:50.

6 Wolhuter CC, Peckham G, van der Walt JL, et al. The research output of female academics at a South African university: progress with gender equity? Africa Education Review 2013;10:148-66.

7 Hyder AA, Akhter T, Qayyum A. Capacity development for health research in Pakistan: the effects of doctoral training. Health Policy Plan 2003;18:338-43.

8 Sam-Agudu NA, Paintsil E, Aliyu MH, et al. Building sustainable local capacity for global health research in West Africa. Ann Glob Health 2016;82:1010-25.

9 Chu KM, Jayaraman S, Kyamanywa P, et al. Building research capacity in Africa: equity and global health collaborations. PLoS Med 2014;11:e1001612.

10 Abimbola S. The foreign gaze: authorship in academic global health. BMJ Glob Health 2019;4:e002068.

11 World Health Organisation. Who Hinari eligibility. Geneva, 2020. Available: https://www.who.int/hinari/eligibility/en/\#: :text=Hinari\% 20Eligibility\%20Hinari\%20Core\%20Offer\%20includes\%20two\% 20 groups,the $\% 20$ publications $\% 20$ through\%20the $\% 20$ Core $\%$ 200ffer\%20of\%20Hinari [Accessed 6 Aug 2020].

12 Hagenhoff S, Blumenstiel M, Ortelbach B. An empirical analysis of the amount of publication fees. Serials Review 2008;34:257-66.

13 Björk BC, Solomon D. Pricing principles used by scholarly open access publishers. Learned Publishing 2012;25:132-7.

14 Van Noorden R. Open access: the true cost of science publishing. Nature 2013;495:426-9.

15 Altbach PG. Academic Salaries and Contracts. In: The International imperative in higher education. Rotterdam: SensePublishers (Global Perspectives on Higher Education), 2013: 61-4.

16 Tijssen RJW. Africa's contribution to the worldwide research literature: New analytical perspectives, trends, and performance indicators. Scientometrics 2007;71:303-27.

17 Ong LL, Mitchell JD. Professors and hamburgers: an international comparison of real academic salaries. Appl Econ 2000;32:869-76.

18 Ahmed I, Shifraw T. Challenges of being a researcher in Africa: a narrative synthesis of literature. Ethiopian Journal of Health Development 2019;33:4.

19 World Health Organisation. Global strategy and plan of action on public health, innovation and intellectual property. Geneva, 2011. 
20 African Union. Scince, technology aend innovation strategy for Africa 2024, 2014. Available: https://au.int/sites/default/files/newsevents/ workingdocuments/33178-wd-stisa-english_-_final.pdf [Accessed 3 Aug 2020].

21 WHO Africa Region Office. WHO Document AFR/RC59/5: The Algiers declaration on Research for Heath: Narrowing the knowledge gap to improve Africa's health. Brazzaville - Congo, 2008.

22 WHO and Government of Mali. The Bamako call for action on research for health: strengthening research for health, development, and equity. Bamako, Mali: From the Global Ministerial Forum on Research for Health, 2008.

23 Development CoHRf. Health research: essential link to equity in development. New York: Oxford University Press, 1990.

24 Communiqué, Abuja. Nigeria. High level Ministerial meeting on health research in Africa 2006.

25 Büyüm AM, Kenney $\mathrm{C}$, Koris $\mathrm{A}$, et al. Decolonising global health: if not now, when? BMJ Glob Health 2020;5:e003394. 